\title{
EDUCATION AND RESEARCH IN ORAL SCIENCE IN THE MASSACHUSETTS INSTITUTE OF TECHNOLOGY
}

$\mathrm{T}$ THE W. K. Kellogg Foundation of Battle Creek, Michigan, has made a grant of 440,000 dollars to the Massachusetts Institute of Technology for the further development of the Oral Science Program of graduate teaching and research in the Department of Nutrition and Food Science. The Oral Science Program in the Institute, directed by Prof. Robert S. Harris, professor of nutritional biochemistry, was established a yoar ago under a four-year grant in excess of 500,000 dollars from the National Institute of Dental Research, a division of the National Institutes of Health at Bethesda, Maryland.

The Kellogg grant, which will be used over a five-year period, represents collaboration among the private Foundation, the Massachusetts Institute of Technology and the National Institutes of Health in development of a broad programme of science-oriented graduate training for dental educators and research workers.

The Oral Science Program was initiated in response to the increasing need for the application of fundamental biological and physical sciences to the solution of problems in oral and dental disease and the growing demand for dental school faculty members, both dentists and life scientists, who possess a depth of understanding in the biological and physical sciences which underlie their professions.

Thus, the principal objectives of the Program embrace both the areas of professional education and fundamental research in the oral sciences. The Department of Nutrition and Food Science in the Massachusetts Institute of Technology was selected as the location for the Program, even though the Institute does not operate a dental school, because of the growing recognition of the importance of food and nutrition to dental health and because of the Institute's broad base in the underlying biological and physical sciences.

Several investigations are being carried out under the twin grants in the area of professional education, and foremost among these is a programme of graduate training in nutrition and oral science leading to a Ph.D. degree for selected graduate dentists and bioscientists of outstanding merit who will follow careers in dental education and research. This programme will normally require four years of study. Two post-doctoral students entered the programme a year ago; three more began recently, and eventually the number will increase to $15-20$. 'The grant of the National Institutes of Health is being used to support students and their research. A substantial portion of the Kellogg grant will be used to provide specialized laboratories and clinical facilities.

A prime aim of the Ph.D. programme in oral science is to help broaden the scientific basis of America's dental school faculties and curricula by serving as a training centre for individuals who may become leaders in dental education and research. It is hoped that one result will be the eventual scientific broadening of the professional education provided to the nation's dental practitioners.

According to Prof. Harris, the research strides being made in understanding and preventing oral diseases, especially dental decay, will have the long-range effect of bringing about fundamental changes in the character of dental practice. Practitioners, in order to meet the demands of theso changes, will need a broadened training in basic science in the course of their professional dental education.

Other activities being undertaken in this Oral Science Program to contributo to professional education include short summer courses for dentists and dental faculty members in nutrition and related biosciences, special seminars and conferences, educational television programmes directed to dental practitioners, and the publication and dissemination of research findings and critical reviews. There will also be activities intended to inform the lay public how nutrition and oral hygiene affect the teeth and gums.

Research under the Oral Science Program is focused on the biochemical, microbial and nutritional aspects of oral pathology. Much fundamental work remains to be done before a clear understanding can be obtained of the relationships between human nutrition, food-borne microbial agents, and human biochemical systems, and of their combined effects on oral and dental disease and health. [See also Nature, 204, 526; 1964.]

\section{THE NUFFIELD FOUNDATION}

$\mathrm{T}$ HE nineteenth annual report of the Nuffield Foundation* covers the year ended March 31,1964 . It includes a just and dignified tribute to Lord Nuffield's interest in healing and research and civic welfare throughout the Commonwealth, as well as an appreciation of Mr. L. Farrer-Brown's services as director, from which office he retired at the end of the year. During the period covered allocations were made totalling $£ 1,785,963$, of which $£ 240,493$ was for biological research, $£ 40,000$ for research in rheumatism, $£ 353,600$ for other medical research, $£ 322,300$ for social research and experiment, $£ 418,103$ for education, and $£ 407,535$ for grants for the Commonwealth overseas. While the allocations followed the pattern of previous years, emphasis was placed on two grants for medical research, one of which, up to $£ 350,000$ to establish a unit for medical genetics in the University of Liverpool, is the largest single grant yet made by the Foundation for medical research. The other grant is one of $£ 50,000$ to the Royal College of Surgeons for a building

- The Nuffield Foundation. Report for the year ended March 31, 1964 (Nineteenth Report, 1963-64.) Pp. xvi $204+2$ plates. (London: The Nuffield Foundation, 1964.) at its Buckston Browne Farm to set up a colony of monkeys, including a section devoted to breeding, with the primary purpose of enabling the Department of Dental Science to make experimental investigations into dental caries. In directing attention to this grant the trustees comment that since 1946 the Foundation's support for dental research has been largely limited to its scheme of dental fellowships and scholarships and that the paucity of research grants reflects the lack of applications rather than any decline in interest by the Foundation.

With the last-mentioned observation should be set the later, more general, comment that, although the number of research applications submitted to the trustees in. creased during the year, there was not the overwhelming flood of applications that might have been expected from reports during the year of widespread lack of funds for research. In medicine and biology the Foundation made slightly fewer grants than in $1962-63$, and the increase in the allocation reflects an increase in the average size of the grants. In the social sciences both the number of grants and their average size increased. The trustees do not 
anticipate any long-term decrease in the requests of the universities for Foundation support as a result of any Government action on the Robbins Report. On the contrary, the expected general increase in academic research may itself generate new demands, and perhaps also enable the Foundation in its choice of projects to adhere more closely to those areas most consonant with its policies and commission. Private foundations generally may well expect that their opportunities for useful action will always outrun thoir resources.

The $£ 40,000$ for research into rheumatism already noted includes a grant of $£ 34,740$ to the Middlesex Hospital Medical School to establish an Experimental Immunological Unit for the purpose of carrying out investigations into auto-immune phenomena in rheumatoid disease. Other grants for medical research include $£ 52,800$ over. 5 years to the Department of Social and Occupational Medicine of the Welsh National School of Medicine for an investigation of bronchitis among steelworkers at Ebbw Vale and Port Talbot, and a further grant of $£ 33,350$ to the Unit of Biometry, University of Oxford, towards the cost of a small Elliot 803 computer, but the report records the failure, for lack of industrial support, of the promising occupational hygiene service at Slough. A grant of $£ 15,000$ over 5 years has been made in support of Dr. Stephen Black's investigation, by electroencephalogram studies and psychophysiological techniques, of the brain's responses to stimuli in different sensory modalities, and one of $£ 11,000$ to support studies of exploratory behaviour in children at the Park Hospital for Children, Oxford, for a period of 5 years.

Among the grants for biological and other scientifie research may be noted one of $£ 29,000$ over 5 years to the Department of Botany, University of Cambridge, for an investigation into the mechanism governing the uptake and loss of ions by plant cells, and the distribution of ions within the tissue of the whole plant, while one of $£ 42,150$ over 5 years to the School of Biological Sciences, University of East Anglia, is to permit the building up of a team to study ion and water uptake by the roots of higher plants. A grant of $£ 71,681$ was made to provide accommodation for research at the Department of Botany, University of Glasgow, more particularly for research on the physiology of parasites, while a capital grant of $£ 46,500$ to the Strangeways Research Laboratory, Cambridge, now the largest centre for cell biology in Britain, is for equipment and increased accommodation for the Biophysics Section, particularly for investigation of the fibrous proteins of connective tissue and the constituents of the ground substance at different levels of structure. A grant of $£ 11,250$ over 3 years was made to the Department of Organic Chemistry, University of Manchester, for research into the transport of organic molecules across cell membranes, and £12,155 to the Department of Zoology. University of Shoffield, in support of biophysical work on the interaction of steroid hormones with macromolecular structures in the cell.

A new grant of $£ 35,000$ over 5 years was made to the Department of Metallurgy, Imperial College of Science and Technology, London, to enable a research group to be built up in process engineering metallurgy, while the Foundation is also assisting the Advanced School of Automobile Engineering, Cranfield, to develop its research activities with a grant of $£ 15,000$ over 5 years for an investigation of the effects of vibration on comfort and human performance. The Foundation has provided up to $£ 250,000$ to the Royal Society towards half the cost of the necessary reconstruction of part of Carlton House Terrace. on the understanding that the Government will secure the premises to the Society without charge for at least 99 years.

Of the grants for social research and experiment, the trustees direct particular attention to five: first, one of $£ 70,000$ over 5 years was made to the Institute of Race Relations for a survey of relations between the coloured communities in Britain and their host community secondly, $£ 45,000$ over 4 years went to Prof. C. Buchanan of the Department of Civil Engineering, Imperial Colleg. of Science and Technology, for transport studies; thirdly, $£ 42,000$ over 4 years to the Institute for Operational Research for research into the planning processes of a local government authority; fourthly, $£ 15,000$ over a year and a half to the National Institute for Economic and Social Research for a study of the costs of bringing all the urban parts of Britain up to satisfactory standards in housing and other urban facilities; and, fifthly, $\mathfrak{£ 3 0 , 0 0 0}$ over 3 years to the Institute of Community Studies for the development of its plans for research through social experiments. A grant of $£ 9,000$ over 3 years was also made, to the Institute of Social and Economic Resoarch, University of York, for a study of the social and economic problems of urban redevelopment in the West Riding, while a similar grant was made to the Department of Social and Economic Research, University of Glasgow, for a comparative study of European regional economic: problems. A further grant of $£ 10,000$ over 6 yoars was made to the Institute of Strategic Studies for its library, and a grant of $£ 20,000$ to Political and Economic Planning was to help with the removal to new premises; while one of $£ 3,000$ over 2 years went to the School of Architecture, University of Cambridge, for research into the design of science lecture-rooms.

Of the grants for education, one of $£ 60,000$ to the London School of Economics to finance a Unit for Economic and Statistical Studies on Higher Education is specially emphasized by the trustees. In the first place, the Unit will examine the relation between higher educa tion, the structure of the labour force and economic: growth, and will assess the demand from school-leavers for entry into different kinds of education beyond the compulsory school age and the relation of this demand to social, cconomic and educational factors. The Foundation is also particularly interested in investigations of language development and in fundamental work on intellectual development based on present-day biological research. A further $£ 175,000$ was allocated for the Science Toaching Programme, $\mathfrak{f 7 5 , 0 0 0}$ was set aside for a project in science for 5-13-year-olds, and allocations of $£ 6,000$ were made for each of three groups concerned with identifying the main strategy and objectives in planning teaching material for physics, chemistry and biology at the Advanced Level of the General Certificate of Educa. tion. Of the $£ 100,000$ set aside for the Language Teaching Programme, $£ 50,000$ has been allocated to the Language Teaching Materials Project, and a grant of $£ 22,000$ ove three years was made to the Communication Research Centre, University College, London, for research into the English language designed to contribute to the teachin of English in schools; $£ 20,500$ over five years to the Department of Psychology, University of Cambridge, for further investigation of the effect of personality factors on intellectual development; $£ 10,500$ over three years to the Department of Psychology, University of Hull, for research into learning transfer in young children; and $£ 6,600$ over three years to the Department of Statistics. University College, London, for research into universityselection and performance.

Grants for the Commonwealth overseas include up to

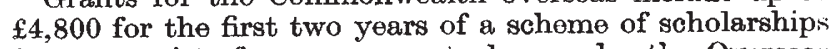
for economists from overseas to be run by the Overseas Development Institute; a further grant of $£ 100,000$ over five years to the Centre for Educational Television Overseas; and a final grant of $£ 20,000$ over three years to the Overseas Visual Aid Centre, conditional on satisfactory financial support from Government sources. A grant of $£ 16,000$ was made to the University of Ibadan to provide a nuclear magnetic resonance spectroscope for research on natural products in the Department of Chemistry; $£ 26,050$ over the next four years to the Nuffield Unit of Tropical Animal Ecology at Mweyz in Queen Elizabeth 
National Park, Uganda; up to $£ 12,000$ for the production of a film illustrating the work on teacher training in the Kilimanjaro district of Northern Tanganyika; a further $£ 7,500$ for investigations in terrestrial ecology jointly by the University College of Rhodesia and Nyasaland and the University of Witwatersrand; and $£ 3,800$ over three years for research into the vegetation of swamps by Makerere College, University of East Africa. A grant of $£ 80,000$ was made to the Walter and Eliza Hall Institute of Medical Research, Molbourne, for extensions for immunological research, a similar grant to enable the Sydney Church of England Homes for Aged Persons to obtain a site and erect the Nuffield Garden Village, and $£ 2,640$ over three years for investigations by the Depart. ment of Biochemistry, University of Adelaide, into the association of deoxyribonucleic acid and the yeast cytochrome $b_{2}$ from which it is isolated and of the way in which deoxyribonucleic acid controls the behaviour of yeast. The University of Hong Kong received a grant of $£ 26,650$ over three years towards research in the Department of Zoology into the level of adrenocorticosteroids at cellular level, and one of $£ 15,000$ was made to the British Solomon Islands Protectorate for training college accom. modation for women students.

As an experiment, the Foundation offered a special award for a medical fellowship to be held in Ibadan, Makerere, Vollore or the University of the West Indies, but although there was keen competition for the ordinary fellowships, of which four were awarded, only one candidate applied for the special fellowship, and as he did not wish to follow an academic career in medicine no award was made. One medical research fellowship was awarded, four fellowships, three assistantships for general practitioners, and 24 scholarships in tropical medicine, enabling senior students to spend three months attached to a Commonwealth medical school in the tropics. One research fellowship, five fellowships and three scholarships in dentistry were awarded, and the first six awards were made under the new scheme for food science. Two scholarships were awarded under the new scheme for sociological awards, and awards under the schemes for the Dominions and Colonies included 20 Dominion fellowships. (six in medicine, eight in science, six in the humanitios and social sciences) for graduates from Australia, Ceylon, India, Pakistan and New Zealand; three travelling fellowships for Canadian public officials and two for trade unionists; and nine short-term travel grants for senior Canadian scholars (one in medicine, five in science, three in the humanities and the social sciences). Two fellowships were awarded to Civil Servants from Pakistan; and under the scheme for training Africans in agriculture, a scholarship was awarded to a farmer from Kenya. The Foundation's grant to the joint scheme with the Royal Society for Commonwealth Bursaries was renewed for a further, final period of five years at $£ 5,000$ a year, and 24 awards were made.

\section{COMBUSTION}

$\mathrm{T}$ HE tenth International Symposium on Combustion was held in the Department of Physical Chemistry, University of Cambridge, during August 16-21, 1964. Nearly 700 chemists, physicists and engineers from 25 countries attended. Among the overseas visitors were Dr. Bernard Lewis (President of the Combustion Institute) and Profs. Kistiakowsky, Kondratiev, Laffitte, Jost and Von Elbe.

The Plenary Lecture, entitled "The Study of Combustion by Photochemical Methods", was delivered by Prof. R. G. W. Norrish (Cambridge), who gave a broad survey of the development of understanding of the basic processes of combustion over the past forty years, with particular reference to the contributions made by kinetic spectroscopy and flash photolysis. The lecture was preceded by a short inaugural meeting and the presentation of the Combustion Institute Awards: the Sir Alfred Egerton Medal to Prof. P. Laffitte (Paris), the Bernard Lewis Medal to Prof. R. G. W. Norrish, and the Silver Combustion Medal, for the best paper presented at the ninth Symposium, to N. M. Howe, jun., C. W. Shipman and A. Vranos.

The papers in the discussion under the title "Elemen. tary Combustion Reactions" fell into two groups - sixteen concerned with neutral species and nine with charged species. The review paper in the first group, "Elementary Combustion Reactions", was given by Prof. Ashmore (Manchester). The papers which followed centred round several topics. F. J. Wright (Esso Research) spoke on the nature of initial attack by oxygen atoms; C. F. Cullis, A. Fish and J. F. Gibson (Imperial College of Science and Technology) on the mechanism of spontaneous ignition of hydrocarbon mixtures; R. V. Blundell et al. (Dundee) on methane oxidation; G. B. Kistiakowsky and colleagues (Harvard) on methane and acetylene oxidation in shock waves; R. R. Baldwin and colleagues (Hull) on the use of the $\mathrm{H}_{2}-\mathrm{O}_{2}$ reaction for investigating the reactions between $\mathrm{H}$ and $\mathrm{O}$ atoms and $\mathrm{OH}$ and $\mathrm{HO}_{2}$ radicals and hydrocarbons. G. Dixon-Lewis, M. M. Sutton and A. Williams (Leeds) reported measurements made in $\mathrm{H}_{2}-\mathrm{O}_{2}$ flames on the reaction rates of $\mathrm{H}$ atoms with $\mathrm{O}_{2}, \mathrm{D}_{2} \mathrm{O}$ and $\mathrm{CO}_{2}$.
P. Gray (Leeds) and J. C. J. Thynne (Edinburgh) discussed the kinetics of $\mathrm{H}$ atom abstraction by methyl radicals from substances containing the $\mathrm{N}-\mathrm{H}$ bond, and $\mathrm{L}$. Phillips and R. Shaw (Explosives Research and Develop. ment Establishment) discussed the reactions of methyl and methoxy radicals with $\mathrm{NO}$ and $\mathrm{NO}_{2}$. The effect of $\mathrm{SO}_{2}$ on $\mathrm{H}_{2}-\mathrm{O}_{2}$ explosion limits was considered by $P$. Webster and A. D. Walsh (Dundee). Several authors discussed atom and radical recombination: F. S. Larkin and B. A. Thrush (Cambridge), H atoms; K. L. Wray (Avco-Everett Research Laboratories), $\mathrm{O}$ atoms; C. P. Fenimore and G. W. Jones (General Electric Research Laboratories), radical recombination and heat release. J. R. Airey, J. C. Polanyi and D. R. Snelling (Toronto) considered hydrogen-halogen chain reactions. Carbon formation in premixed hydrocarbon-oxygen flames at reduced pressure was the subject of a paper by U. Bonne, K. H. Homann and H. Gg. Wagner (Göttingen), in which evidence was presented suggesting a correlation between the formation of poly-acetylenes in the reaction zone and the appearance and growth of soot particles. (Soot formation was also considered by K. S. Narasimhan and P. J. Foster in the General Session.) An interesting paper by A. A. Westenberg and R. M. Fristrom (Johns Hopkins) discussed a promising method of measuring freo radical concentrations in flames by electron spin resonance. With probe sampling of flame gases combined with standard electron spin resonance techniques and using $\mathrm{O}_{2}$ as a reference gas, they obtained absolute $\mathrm{O}$ and $\mathrm{H}$ atom profiles in hydrocarbon-oxygen flames at reduced pressure.

The second group of papers, concerned with ions, was preceded by a review, "Charged Species", by Dr. T. M. Sugden ('Shell' Research). Several papers in this section discussed the mechanism of chemionization in flames. In contrast to the ninth Symposium, where there appeared to be general agreement about the $\mathrm{CH}+\mathrm{O} \rightarrow \mathrm{CHO}$ mechanism, there was no such agreement here. Prof. Kistiakowsky and colleagues (Harvard), on the basis of shock tube experiments, revived an earlier suggestion of Knewstubb and Sugden (later dismissed by them) that 